\title{
PENGARUH DAUN TURI (Sesbania grandiflora) DAN LAMTORO (Leucaena leucocephala) DALAM RANSUM SAPI BERBASIS INDEKS SINKRONISASI PROTEIN - ENERGI TERHADAP SINTESIS PROTEIN MIKROBA RUMEN
}

\author{
Afduha Nurus Syamsi, Fransisca Maria Suhartati dan Wardhana Suryapratama \\ Fakultas Peternakan Universitas Jenderal Soedirman \\ Email : nurussyamsiafduha@gmail.com
}

\begin{abstract}
An experiment was aimed to assess the use of the legume leaf as a source of protein feedstuff and levels of synchronization protein-energy (SPE) index in the diet of cattles on ammonia (N-NH3) and microbial protein synthesis (MPS). In vitro techniques was done. The research was used a completely randomized design (CRD), with factorially pattern (2x3), the first factor was the two species of legume (Sesbania leaves and Leucaena leaves) and the second factor was the three level of the SPE index (0.4, 0.5, and 0.6), there were 6 treatment combinations and each was 4 replicates. The results showed that no interaction between legume with SPE index, but each factor was significantly effect $(\mathrm{P}<0.05)$ on $\mathrm{N}-\mathrm{NH}_{3}$ of rumen fluid and MPS. The research concluded that Leucaena leaf is a legume that is better than Sesbania leaf in terms of their ability to increase MPS. SPE index is the best in producing MPS at level o.6.
\end{abstract}

Key words: Legume, synchronization of protein and energy index, ammonia, microbial protein synthesis

\section{PENDAHULUAN}

Sapi potong maupun sapi perah sebagai ternak ruminansia membutuhkan asupan nutrien pakan yang cukup untuk memenuhi kebutuhan pokok dan produksinya. Pakan sapi umumnya terdiri dari hijauan dan konsentrat. Tanaman hijauan yang potensial dan mempunyai nilai hayati tinggi adalah tanaman leguminosa. Menurut Utomo (2012), leguminosa merupakan proteinceus roughages yaitu sumber pakan serat berprotein tinggi. Kandungan protein leguminosa rata-rata mencapai $22 \%$ (Kushartono dan Iriani, 2004). Berlainan dengan sumber serat, sumber energi pakan sapi biasanya berasal dari limbah pertanian dan hasil sisa pengolahan pangan seperti dedak, onggok, dan pollard. Cakra dan Siti (2008) menyatakan bahwa pemberian sumber energi dalam pakan ternak penting untuk diperhatikan, karena dapat meningkatkan koefisien cerna nutrien ransum. Oleh karena itu, pemberian leguminosa dan bahan pakan sumber energi merupakan suatu kombinasi bahan pakan yang baik bagi sapi.

Pemberian leguminosa sebagai sumber protein dan pemberian bahan pakan sumber energi bagi sapi harus mampu meningkatkan sintesis protein mikroba rumen (SPM), karena hewan ruminansia sangat bergantung pada keberadaan mikroba rumen dalam proses fermentasi pakan. Sintesis protein mikroba rumen (SPM) membutuhkan senyawa amonia yang tidak berlebihan dan energi sebagai rantai karbon dari degradasi karbohidrat dalam jumlah yang cukup.
Menurut Widyobroto et al. (2007), suplai protein dan energi tersebut harus tersedia secara simultan (sinkron) agar proses SPM menjadi optimum. Ginting (2005) manyatakan bahwa efek asynchronous antara protein dan energi akan menimbulkan kerugian, apabila substansi protein terdegradasi lebih cepat dibandingkan sumber energi, maka sebagain besar protein dalam bentuk amonia akan terbuang melalui urin. Sebaliknya, apabila substansi sumber energi terfermentasi lebih cepat, maka akan terjadi akumulasi asam laktat dan dapat memicu terjadinya penurunan $\mathrm{pH}$ rumen yang dapat menyebabkan asidosis. Suplai ammonia dan energi yang sinkron dapat dicapai dengan penyesuaian degradasi protein dan fermentabilitas karbohidrat atau bahan organik (BO) dalam rumen.

Laju degradasi protein asal leguminosa rendah di dalam rumen karena berada dalam ikatan kompleks bersama tanin (Hadi et al., 2011), sedangkan laju fermentabilitas BO pakan asal pengolahan pangan berada pada taraf sedang hingga tinggi. Perbedaan laju degradasi tersebut dapat diatasi dengan formulasi ransum berbasis indeks sinkronisasi protein-energi (SPE). Menurut Sinclair et al. (1993), penyusunan ransum berbasis indeks SPE berusaha menunjukkan keharmonisan degradasi protein dan fermentabilitas BO dalam rumen per jam yang dinyatakan secara kauntitatif dengan indeks optimum yaitu 1. Baik laju degradasi protein atau BO, juga indeks SPE bahan pakan lokal (termasuk leguminosa) belum terinventarisir dengan baik. Oleh karena itu, 
dibutuhkan kajian tentang pengaruh interaksi antara penggunaan leguminosa dan level indeks SPE terhadap produk fermentasi rumen terutama kadar amonia cairan rumen dan sintesis protein mikroba (SPM) rumen.

\section{METODE PENELITIAN}

Penelitian diawali mengukur degradasi protein dan BO delapan jenis bahan pakan (rumput raja, daun turi, daun lamtoro, onggok, dedak, pollard, ampas tahu, dan bungkil kelapa) secara in vitro menurut metode Tilley dan Terry (1963) yang dimodifikasi dengan metode Orskov dan Mcdonald (1979) untuk menetapkan indeks sinkronisasi protein-energi (SPE). Laju degradasi protein dan bahan organik (BO) bahan pakan digunakan untuk menghitung indeks SPE menurut petunjuk Hermon et al. (2008).

Indeks Sinkronisasi $=$

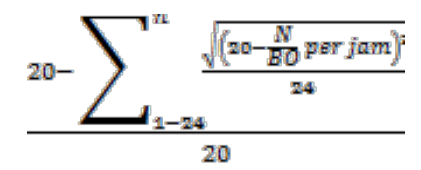

Keterangan :

$\mathrm{n}$ : waktu pengamatan, N/BO per jam : laju degradasi protein dibanding laju degradasi bahan organik setiap jam (Hermon et al., 2008).

Penelitian eksperimental dilakukan untuk mengukur kadar amonia dan SPM cairan rumen sapi perah secara in vitro (Tilley dan Terry, 1963). Materi yang digunakan adalah cairan rumen sapi Peranakan Friesian Holstein (PFH) jantan yang diambil dari rumah potong hewan (RPH) Mersi, Purwokerto, segera setelah sapi dipotong. Rancangan percobaan yang digunakan yaitu rancangan acak lengkap (RAL) dengan pola faktorial (2x3), faktor A adalah leguminosa (turi dan lamtoro), faktor B adalah indeks SPE $(0,4 ; 0,5$; dan 0,6$)$. Terdapat 6 kombinasi perlakuan dan masing-masing diulang sebanyak 4 kali. Pengukuran kadar N-NH3 menggunakan tekhnik mikrodifusi conwey (General Laboratory Procedures, 1966), sedangkan sintesis protein mikroba rumen (SPM) diukur dengan metode Zinn dan Owen (1986). Penelitian dilakukan di Laboratorium Ilmu Nutrisi dan Makanan Ternak, Fakultas Peternakan Universitas Jenderal Soedirman pada medio Mei-Juli 2015.

\section{HASIL DAN PEMBAHASAN}

Hasil pengamatan laju degradasi protein rumput raja, daun turi, daun lamtoro, onggok, dedak, pollard, ampas tahu, dan bungkil kelapa masingmasing yaitu 2,2625, 5,4914, 4,7329, 1,2772, 3,2501, 7,0444, 6,5594, dan 7,5464 g N/jam, sedangkan laju degradasi bahan organik (BO) masing-masing bahan pakan yaitu 0,0103, 0,0164, 0,0135, 0,0080, 0,0091, 0,0236, 0,0203, dan 0,0524 kg BO/jam, dapat dilihat ilustrasinya pada Gambar 1.
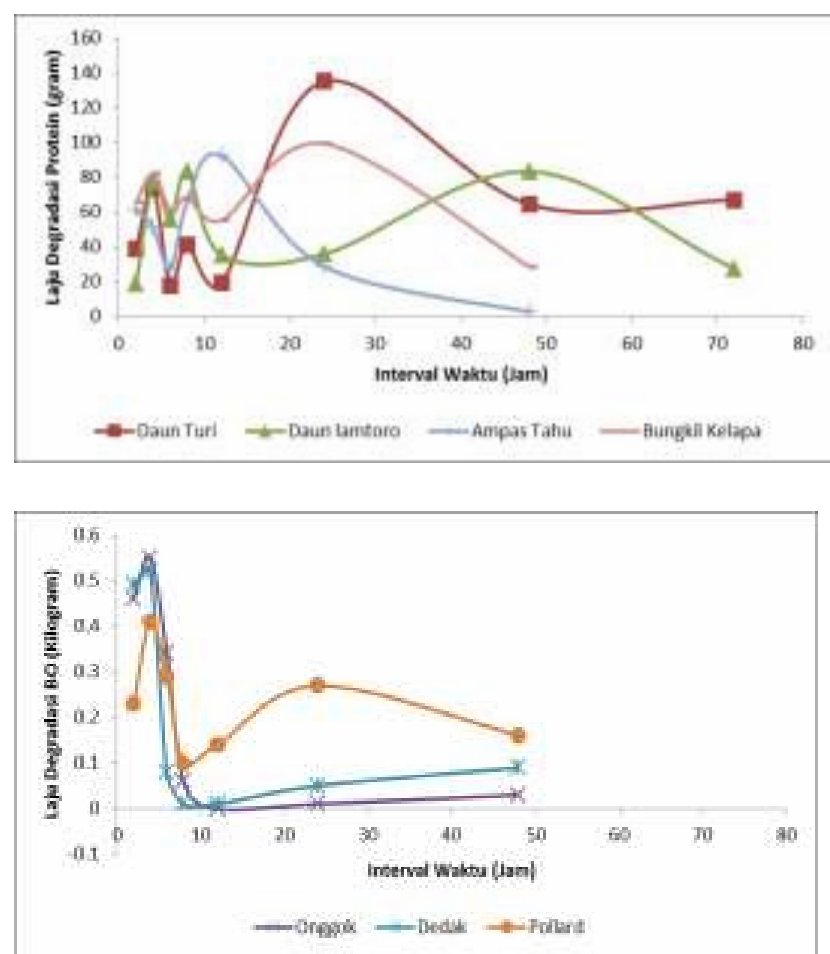

Gambar 1. Laju degradasi protein bahan pakan sumber protein (atas) dan BO bahan pakan sumber energi (bawah) pada interval waktu berbeda.

Grafik laju degradasi protein menunjukkan bahwa penurunan dan peningkatan degradasi protein masing-masing bahan pakan sumber protein memiliki kecenderungan yang sama, namun berbeda setelah jam ke 12. Menurut Hadi et al.(2011), degradasi protein leguminosa cenderung rendah karena adanya ikatan matrix bersama tanin. Menurut Suryahadi (1990), ampas tahu memiliki degradasi protein yang cukup tinggi di dalam rumen, degradasi protein akan tinggi sejak jam ke o hingga jam ke 4 dan konstan menurun pada jam berikutnya. Menurut Zamsari et al. (2012), protein bungkil kelapa memiliki kecenderungan degradasi yang tinggi di dalam rumen. Berbeda dengan degradasi protein, degradasi BO bahan pakan sumber energi memiliki kecenderungan trend yang sama pada setiap interval waktu, yaitu meningkat pada jam ke dua hingga ke empat dan drastis menurun setelah jam keempat dan stabil pada jam berikutnya, kecuali pada pollard. Hal tersebut sesuai dengan pendapat Steven dan Hume (1998) yang menyatakan bahwa fermentasi bahan pakan sumber energi tertinggi pada o-4 jam dalam cairan rumen dan menurun

Data penelitian menunjukkan bahwa bahan pakan dengan indeks sinkronisasi rendah adalah dedak $(0,29)$, daun lamtoro $(0,31)$, daun turi $(0,34)$ dan ampas tahu $(0,37)$. Bahan pakan dengan indeks 
medium adalah pollard $(0,42)$ dan rumput raja $(0,58)$, sedangkan bahan pakan dengan indeks tinggi adalah onggok $(0,71)$ dan bungkil kelapa $(0,74)$. Berdasarkan indeks SPE tersebut disusunlah ransum berbasis indeks SPE seperti pada Tabel 1.

Tabel 1. Susunan ransum perlakuan berbasis indeks sinkronisasi protein dan energi energi (SPE)

\begin{tabular}{|c|c|c|c|c|c|c|c|}
\hline & \multirow{2}{*}{ Bahan Pakan } & $\mathrm{R} 1$ & $\mathrm{R} 2$ & R3 & R4 & R5 & R6 \\
\hline & & \multicolumn{6}{|c|}{ 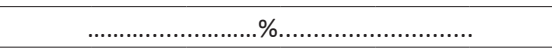 } \\
\hline 1 & Rumput Raja & 35 & 50 & 54 & 35 & 50 & 54 \\
\hline 2 & Daun Turi & 10 & 10 & 10 & 0 & 0 & 0 \\
\hline 3 & Daun Lamtoro & 0 & 0 & 0 & 10 & 10 & 10 \\
\hline 4 & Onggok & 3 & 6 & 15 & 3 & 6 & 15 \\
\hline 5 & Dedak & 26 & 14 & 1 & 26 & 14 & 1 \\
\hline 6 & Pollard & 8 & 5 & 3 & 8 & 5 & 3 \\
\hline 7 & Ampas Tahu & 14 & 9 & 3 & 14 & 9 & 3 \\
\hline 8 & Bungkil Kelapa & 3 & 5 & 13 & 3 & 5 & 13 \\
\hline 9 & Mineral & 1 & 1 & 1 & 1 & 1 & 1 \\
\hline \multicolumn{2}{|c|}{ Total } & 100 & 100 & 100 & 100 & 100 & 100 \\
\hline \multicolumn{2}{|c|}{ Indek Sinkronisasi } & 0,4 & 0,5 & 0,6 & 0,4 & 0,5 & 0,6 \\
\hline \multicolumn{8}{|c|}{ Nutrien } \\
\hline \multicolumn{2}{|c|}{ Bahan Kering, \% } & 92.61 & 93.30 & 92.75 & 92.58 & 93.27 & 92.71 \\
\hline \multicolumn{2}{|c|}{ Protein Kasar, \% BK } & 12.29 & 12.24 & 12.53 & 12.25 & 12.19 & 12.49 \\
\hline \multicolumn{2}{|c|}{ Lemak Kasar, \% BK } & 5.31 & 5.35 & 5.97 & 5.49 & 5.54 & 6.16 \\
\hline \multicolumn{2}{|c|}{ Serat Kasar, \% BK } & 21.21 & 23.18 & 23.13 & 21.17 & 23.14 & 23.08 \\
\hline \multicolumn{2}{|c|}{ BETN, \% BK } & 50.37 & 48.77 & 49.02 & 50.37 & 48.76 & 49.01 \\
\hline \multicolumn{2}{|c|}{ TDN, \% } & 68.02 & 66.39 & 67.16 & 68.23 & 66.59 & 67.37 \\
\hline \multicolumn{8}{|c|}{$\begin{array}{r}\text { Keterangan : (R : Ransum Perlakuan), (Kadar nutrien dihitung berdasarkan: Has } \\
\text { Analisis Laboratorium Ilmu Nutrisi dan Makanan Ternak Fakulta } \\
\text { Peternakan Unsoed, 2015), (TDN : dihitung dengan rumus \% TDN } \\
\text { 70,60 + 0,259 PK + 1,01 LK - 0,76 SK + 0,0991 BETN (Sutardi, 2001) }\end{array}$} \\
\hline
\end{tabular}

\section{Kadar Amonia (N-NH3) Cairan Rumen}

Rataan kadar $\mathrm{N}-\mathrm{NH}_{3}$ hasil pengamatan penelitian berada pada kisaran 12,15-13,53 $\mathrm{mM}$ cairan rumen (Tabel 2). Menurut McDonald et al. (1987), kisaran konsentrasi amonia yang cukup untuk pertumbuhan mikroba yang maksimal adalah $85-300 \mathrm{mg} / \mathrm{L}$ atau setara dengan 2,7 - 14,3 mM cairan rumen. Hasil analisis variansi menunjukkan bahwa tidak ada interaksi antara spesies leguminosa dan indeks SPE terhadap kadar $\mathrm{N}-\mathrm{NH}_{3}$, tetapi perlakuan leguminosa dan indeks sinkronisasi masing- masing berpengaruh nyata terhadap kadar $\mathrm{N}-\mathrm{NH}_{3}(\mathrm{P}<\mathrm{O}, 05)$.

Berdasarkan hasil penelitian diketahui bahwa rataan kadar $\mathrm{N}^{-\mathrm{NH}_{3}}$ cairan rumen yang mendapat daun turi lebih tinggi $(12,79 \mathrm{mM})$ dibandingkan dengan yang mendapat daun lamtoro $(12,10 \mathrm{mM})$. Hal tersebut terjadi karena kecernaan protein daun turi lebih tinggi dibandingkan daun lamtoro (Hadi et al., 2011). Seperti yang diuraikan sebelumnya bahwa daun lamtoro memiliki kadar tanin mencapai 6\% (Pamungkas et al., 2008), sedangkan daun turi memiliki kadar tanin sebesar 0,1\% (Soebarinoto, 1986), sehingga kecernaan protein daun lamtoro menjadi rendah dan sumbangan $\mathrm{NH}_{3}$ dalam cairan rumen juga rendah.

Uji orthogonal polynomial pada faktor B menunjukkan bahwa indeks SPE berpengaruh secara linier terhadap kadar $\mathrm{N}-\mathrm{NH}_{3}$ dengan persamaan $\mathrm{Y}=$ $15,896-6,8937 \mathrm{X}$ dengan koefisien determinasi $\left(\mathrm{r}^{2}\right)$ = 0,42 (Gambar 2). Gambar tersebut menunjukkan bahwa kadarN-NH 3 terus menurun sejalan dengan meningkatnya indeks SPE. Hasil tersebut berbeda dengan hasil penelitian Chumpawade et al. (2005) dan Seo et al. (2010) yaitu bahwa indeks SPE tidak berpengaruh nyata terhadap kadar $\mathrm{N}^{-\mathrm{NH}_{3}}$. Hal tersebut dapat terjadi karena perbedaan metode penelitian, kedua peneliti tersebut menggunakan metode in vivo, sehingga terdapat faktor penyerapan $\mathrm{N}-\mathrm{NH}_{3}$ pada dinding rumen. Selain itu, bahan pakan, materi penelitian dan susunan ransum yang digunakan dalam penelitian tersebut juga berbeda dengan penelitian ini. Basis penelitian Chumpawade et al. (2005) adalah bahan pakan berkualitas rendah yaitu jerami padi, sedangkan Seo et al. (2010) menggunakan bahan pakan penyusun konsentrat yang sangat beragam.

Penurunan kadar $\mathrm{N}^{-\mathrm{NH}_{3}}$ dari indeks SPE rendah $(0,4)$ sampai indeks SPE tinggi $(0,6)$ disebabkan oleh peningkatan sintesis protein mikroba rumen. Bata dan Hidayat (2010) menyatakan bahwa kadar $\mathrm{N}-\mathrm{NH}_{3}$ dalam cairan rumen tergantung pada jenis sumber protein yang digunakan, tingkat degradabilitas sumber protein dalam cairan rumen, dan SPM dalam cairan rumen. Semakin tinggi indeks SPE, maka SPM semakin optimum. Hal tersebut sejalan dengan pendapat Ginting (2005) yang menyatakan bahwa tujuan dari pengaturan indeks SPE adalah untuk menyediakan secara simultan $\mathrm{N}-\mathrm{NH}_{3}$ dan energi untuk kepentingan SPM, sehingga tidak banyak $\mathrm{N}-\mathrm{NH}_{3}$ yang terbuang selama proses fermentasi.

\section{Sintesis Protein Mikroba (SPM) Rumen}

Rataan sintesis protein mikroba rumen (Tabel 2) berada pada kisaran 103,67-142,55 mg/20 ml cairan rumen. Hasil tersebut tidak jauh berbeda dengan hasil penelitian Suhartati (2005) yaitu SPM

Tabel 2. Rataan kadar amonia cairan rumen dan sintesis protein mikroba rumen (SPM)

\begin{tabular}{|c|c|c|c|c|c|c|}
\hline \multirow{2}{*}{ Peubah } & \multicolumn{6}{|c|}{ Perlakuan } \\
\hline & $\mathrm{R} 1$ & $\mathrm{R} 2$ & R3 & R4 & R5 & R6 \\
\hline $\mathrm{NH} 3(\mathrm{mM})$ & $13,53 \pm 0,42$ & $12,71 \pm 0,51$ & $12,15 \pm 0,30$ & $12,65 \pm 0,93$ & $12,38 \pm 0,86$ & $11,28 \pm 0,55$ \\
\hline SPM (mg/20ml) & $103,7 \pm 3,06$ & $110,2 \pm 5,87$ & $120,1 \pm 12,16$ & $106,5 \pm 6,94$ & $116,8 \pm 9,18$ & $142,6 \pm 15,70$ \\
\hline
\end{tabular}

Keterangan : R1 = Turi + Indeks 0,4, R2 = Turi + Indeks 0,5, R3 = Turi + Indeks 0,6, R4 = Lamtoro + indeks 0,4, R5 = Lamtoro + indeks 0,5, R6 = Lamtoro + indeks 0,6 


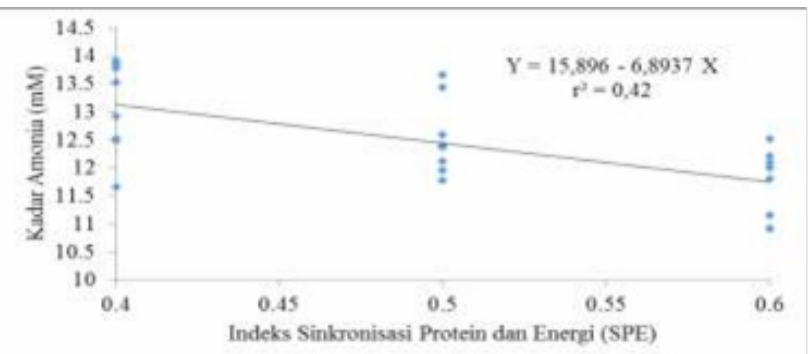

Gambar 2. Pengaruh indeks SPE terhadap kadar N-NH3 cairan rumen

140- $161,6 \mathrm{mg} / 20 \mathrm{ml}$ cairan rumen, tetapi jauh lebih tinggi dibandingkan dengan hasil penelitian Alwi et al. (2013) yaitu 3,98-5,54 mg/20 ml cairan rumen. Kesamaan yang terjadi dengan penelitian Suhartati (2005), karena sama-sama menggunakan leguminosa sebagai percobaan, sedangkan Alwi et al. (2013) menggunakan bagasse tebu fermentasi dengan kandungan protein yang rendah. Hasil analisis variansi menunjukkan bahwa perlakuan leguminosa berpengaruh nyata $(\mathrm{P}<0,05)$ dan perlakuan indeks SPE berpengaruh sangat nyata $(\mathrm{P}<0,01)$ terhadap SPM. Berdasarkan uji beda nyata jujur (BNJ) diketahui bahwa rataan SPM cairan rumen yang mendapat daun lamtoro lebih tinggi $(121,966 \mathrm{mg} / 20$ $\mathrm{ml}$ ) dibandingkan dengan yang mendapat daun turi $(111,310 \mathrm{mg} / 20 \mathrm{ml})$. Hal tersebut diduga disebabkan karena pengaruh tanin yang menyebabkan lambatnya perubahan protein menjadi amonia pada lamtoro. Namun, melambatnya pelepasan amonia tersebut menyebabkan tingkat keharmonisan yang lebih baik dibandingkan dengan turi, sehingga proses sintesis protein mikroba lebih optimum pada penggunaan daun lamtoro.

Hasil uji orthogonal polynomial menunjukkan bahwa indeks SPE berpengaruh secara linier terhadap SPM dengan persamaan $\mathrm{Y}=51,091-131,09 \mathrm{X}$ dengan koefisien determinasi $\left(\mathrm{r}^{2}\right)=0,48$. Gambar 3 menunjukkan bahwa SPM meningkat seiring dengan peningkatan indeks SPE. Hal tersebut sesuai dengan pernyataan Ginting (2005) bahwa intisari dari pengaturan indeks sinkronisasi protein dan energi adalah untuk meningkatkan SPM. Sinkronisasi yang dimaksud adalah adanya keharmonisan dalam penyedian dan atau pelepasan amonia dari protein serta energi dari karbohidrat untuk memenuhi kebutuhan SPM. Sinclair et al. (1993) menyatakan bahwa indeks SPE 1 (satu), menunjukkan adanya keharmonisan antara ketersediaan energi dan protein di dalam cairan rumen. Semakin mendekati angka satu maka semakin meningkat SPM dalam cairan rumen. Menurut Elseed (2005), pemberian sumber protein dan energi secara simultan akan meningkatkan pertumbuhan N mikroorganisme, sedangkan menurut Rotger et al. (2006), angka sinkronisasi protein-energi yang tinggi memiliki kecenderungan meningkatkan $\mathrm{N}$ mikroorganisme di dalam cairan rumen.

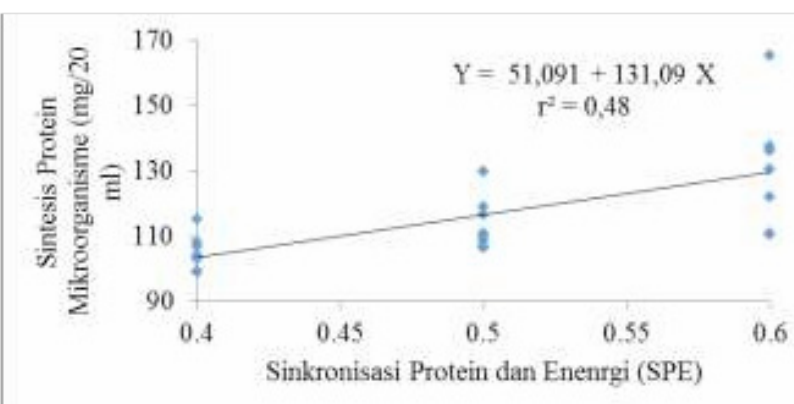

Gambar 3. Pengaruh indeks SPE terhadap SPM cairan rumen

Hasil penelitian juga menunjukkan bahwa terdapat hubungan negatif antara pengamatan konsentrasi amonia dengan SPM (Gambar 4) dengan persamaan Y $=2864,2-19,21 \mathrm{X}(\mathrm{r} 2=0,99))$. Peningkatan SPM dapat diikuti dengan penurunan kadar amonia di dalam cairan rumen. Penurunan kadar amonia rumen bukan disebabkan karena produksinya yang menurun, tetapi karena amonia telah digunakan oleh mikroorganisme dalam sintesis proteinya. Hal tersebut sesuai dengan pernyataan Puastuti dan Mathius (2005) bahwa menurunya konsentrasi $\mathrm{NH}_{3}$ dalam cairan rumen diiringi dengan meningkatnya sintesis protein mikroba. Menurut Nolan (1993), amonia merupakan sumber utama nitrogen yang sangat penting bagi hewan inang. Maynard et al. (1979) menyatakan bahwa $80 \%$ mikroorganisme rumen menggunakan amonia sebagai satu-satunya sumber nitrogen.

Widyobroto et al. (2007) menyatakan bahwa sintesis protein mikroba sangat tergantung pada kadar $\mathrm{N}-\mathrm{NH}_{3}$ dan Alwi et al. (2013) menyatakan bahwa peningkatan sintesis protein mikroba akan diikuti dengan penurunan kadar $\mathrm{N}-\mathrm{NH}_{3}$ dalam cairan rumen. Yang et al. (2010) memiliki pendapat berbeda, bahwa peningkatan sintesis protein mikroba rumen tidak selalu diikuti dengan penurunan kadar $\mathrm{N}-\mathrm{NH}_{3}$, sehingga kadar $\mathrm{N}-\mathrm{NH}_{3}$ tidak selalu dapat menunjukkan tinggi rendahnya SPM. Menurut Bata dan Hidayat (2010), konsentrasi N-NH3 dalam cairan rumen dipengaruhi oleh beberapa faktor, seperti jenis sumber protein yang digunakan, tingkat degradabilitasnya di dalam rumen dan SPM. Artinya bahwa penurunan dan peningkatan $\mathrm{N}-\mathrm{NH}_{3}$ tidak selalu disebabkan oleh SPM, pada suatu kejadian dapat berlaku hal yang berbeda yaitu SPM tinggi dan diikuti dengan kadar $\mathrm{N}-\mathrm{NH}_{3}$ yang tinggi atau kejadian sebaliknya juga dapat berlaku yaitu SPM rendah diikuti dengan kadar $\mathrm{N}-\mathrm{NH} 3$ yang rendah. Cole dan Tood (2008) berpendapat bahwa penggunaan $\mathrm{N}-\mathrm{NH} 3$ dalam SPM tergantung pada ketersediaan energi, sehingga hubungan tersebut akan optimal ketika ketersedian energi juga tercukupi. Produksi 
$\mathrm{N}-\mathrm{NH} 3$ yang tinggi diikuti dengan ketersediaan energi yang tinggi serta keduanya tersedia secara simultan akan meningkatkan SPM. Oleh karena itu, penerapan sinkronisasi protein dan energi dalam penyusunan ransum ternak ruminansia sangat penting untuk diperhatikan, karena dapat meningkatkan SPM dan SPM merupakan sumber protein utama bagi ternak ruminansia.

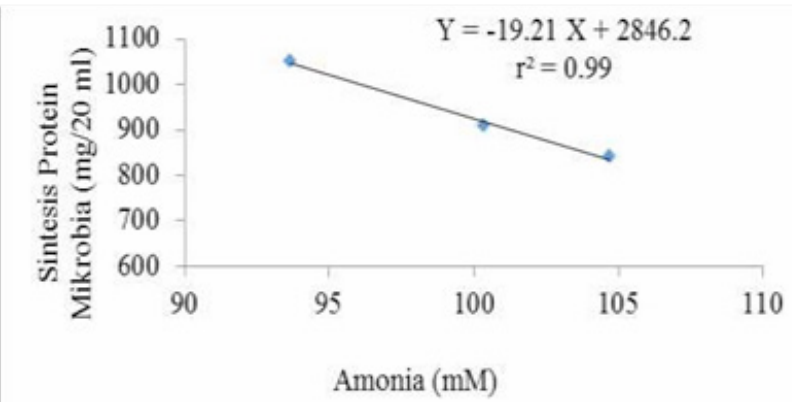

Gambar 4. Hubungan antara kadar amonia cairan rumen dan sintesis protein mikroba rumen

\section{KESIMPULAN}

Kesimpulan penelitian yaitu bahwa daun lamtoro merupakan leguminosa yang lebih baik dibandingkan dengan daun turi ditinjau dari kemampuanya dalam meningkatkan SPM. Indeks SPE yang terbaik dalam menghasilkan SPM yaitu pada level o,6.

\section{DAFTAR PUSTAKA}

Alwi, M., W. Suryapratama dan F.M. Suhartati. 2013. Fermentasi Ampas Tebu (Bagasse) Menggunakan Phanerochaete chrysosporium Sebagai Upaya Meningkatkan Produk Fermentasi Rumen Secara In Vitro. Jurnal ilmiah Peternakan. 1(2): 479-487.

Bata, M. dan N. Hidayat. 2010. Penambahan Molases untuk Meningkatkan Kualitas Amoniasi Jerami Padi dan Pengaruhnya terhadap Produk Fermentasi Rumen Secara In-Vitro. Agripet. 10(2): 27- 33 .

Cakra, I.G.L.O. dan N.W. Siti. 2008. Coefesien Digestibility of Dry Matter and Nutrition Content of Etawah Cross Breed Goat Ration With Forage and Molamik Concentrate. Majalah Ilmiah Peternakan. 11(1): 11-17.

Chumpawadee S., K. Sommart, T. Vongpralub, and V. Pattarajinda. 2005. Effect of Synchronizing The Rate of Degradation of Dietary Energy and Nitrogen Release on Reproductive Performance in Brahman-Thai Native Crossbred Beef Cattle. Songklanakarin Journal Science Technol. 28: 59-68.

Cole, N.A. and R.W. Tood. 2008. Opportunities to
Enhance Performance and Efficiency Through Nutrients Synchrony in Concentrate-Fed Ruminants. Journal of Animal Science.86 : E 318-E 333.

Elseed, F.A.M.A. 2005. Effect of Supplemental Protein Feeding Frequency on Ruminal Characteristics and Microbial N Production in Sheep Fed Treated Rice Straw. Small Rumin. Res. 57:11-17.

General Laboratory Procedures. 1966. General Laboratory Procedures Department of Diary Science. University of Wisconsin, Madison.

Ginting, S.P. 2005. Sinkronisasi Degradasi Protein dan Energi dalam Rumen untuk Memaksimalkan Produksi Protein Mikroba. Wartazoa. 15(1): 1-10.

Hadi, F.H., Kustantinah, dan H. Hartadi. 2011. Kecernaan In Sacco Hijauan Leguminosa dan Hijauan Non-Leguminosa dalam Rumen Sapi Peranakan Ongole. Buletin Peternakan. 35(2): 79-85.

Hermon, M., Suryahadi, K.G. Wiryawan dan S. Hardjosoewignjo. 2008. Nisbah Sinkronisasi Suplai N-Protein dan Energi dalam Rumen Sebagai Basis Formulasi Ransum Ternak Ruminansia. Media Peternakan. 31(3): 186-194.

Kushartono, B dan N. Iriani. 2004. Inventarisasi Keanekaragaman Pakan Hijauan Guna Mendukung Sumber Pakan Ruminansia. Prosiding Temu Teknis Nasional Tenaga Fungsional Pertanian, Balai Penelitian Ternak. Ciawi, Bogor.

Maynard, L. A., J.K Loosli,.H.F Hintz and R.G Warner. 1979. Animal Nutrition, 7th ed. Tata McGraw Hill Publishing Company Limited. New Delhi.

McDonald, P., R.A. Edward, and J.F.D. Greenhalgh. 1987. Animal Nutrition, 8th edition. Longman Group (FE) Ltd. Hongkong.

Orskov E.R., and I. McDonald. 1979. The Estimating of Protein Degradability in The Rumen From Incubation Measurement Weighted Activating to Rate of Passage. Journal of Agrculture Science. Camb. 92: 499-503.

Pamungkas, D., Y.N. Anggraeni, Kusmartono dan N.H. Krishna. 2008. Produksi Asam Lemak Terbang dan Amonia Rumen Sapi Bali pada Imbangan Daun Lamtoro (L. leucocephala) dan Pakan Lengkap yang Berbeda. Seminar Nasional Teknologi Peternakan dan Veteriner. Universitas Brawijaya. Malang.

Puastuti, W. dan I.W. Mathius.2005. Pengaruh Substitusi Bungkil Kedelai Terproteksi Getah Pisang Sebagai Sumber Protein Tahan Degradasi Terhadap Fermentasi Rumen. Seminar Nasional Teknologi Peternakan dan Veteriner. Balai Penelitian Ternak, Bogor.

Rotger, A., A. Ferret, S. Calsamiglia, and X. Manteca. 2006. Effects of Nonstructural Carbohydrates and 
Protein Sources on Intake, Apparent Total Tract Digestibility, and Ruminal Metabolism In Vivo and In Vitro with High-Concentrate Beef Cattle Diets. Journal Animal Science. 84:1188- 1196.

Seo, J.K. ,J. Yang, H.J. Kim, S.D. Upadhaya, W.M. Cho, and J.K. Ha. 2010. Effect of Synchronization of Carbohydrate and Protein Supplay on Ruminal Fermentation. Nitrogen Metabolism and Microbial Protein Synthesis in Holstein Steers. Asian Australian Journal of Animal Science. 23(11) : $1455-1461$.

Sinclair, L.A., P.C. Garnsworthy, J.R. Newbold, and P.J. Buttery. 1993. Effects of Synchronizing The Rate of Dietary Energy and N Release in Diets on Rumen Fermentation and Microbial Rumen Protein Synthesis in Sheep. Journal of Agriculture Science.Camb. 120: 251-263.

Soebarinoto. 1986. Evaluasi Beberapa Hijauan Pohon Leguminosa Tropis Sebagai Sumber Protein untuk Ternak. Disertasi. Pasca Sarjana IPB, Bogor.

Steven, C.E. and I.D. Hume. 1998. Contributions of Microbes in Vertebrate Gastrointestinal Tract to Production and Conservation of Nutrientss. American Psicological Society. 78(2): 393-427.

Suhartati, F.M. 2005. Proteksi Protein Daun Lamtoro (Leucane leucocephala) Menggunakan Tanin, Saponin, Minyak dan Pengaruhnya Terhadap Ruminal Undegradable Dietary Protein (RUDP) dan Sintesis Mikroba Rumen. Animal Production. $7(1): 52-58$.
Suryahadi. 1990. Ruminant Nutrition. Inter-University Centre of Biological Sciences. Bogor Agricultural University. Bogor.

Sutardi, T. 2001. Revitalisasi Peternakan Sapi Perah Melalui Between The Soluble Constitutent Herbage and Their Dry Matter Digestibility. Journal British Feed Science.18: 104-111.

Utomo, R. 2012. Evaluasi Pakan dengan Metode Noninvansif. Citra Ajiprama. Yogyakarta.

Widyobroto, B.P., S.P.S. Budhi dan A. Agus. 2007. Effect of Undegraded Protein and Energy Level on Rumen Fermentation Parameters and Microbial Protein Synthesis in Cattle. Journal Indonesian Tropical Animal Agriculture. 32(3): 194-200.

\Yang, J.Y., J. Seo, H.J. Kim, S.Seo and J.K. Ha. 2010. Nutrients Synchrony: Is it a Suitable Strategy to Improve Nitrogen Utilization and Animal Performance. Asian Australian Journal Animal Science. 23(7): 972-979.

Zamsari, M., Sunarso, dan Sutrisno. 2012. Utilization of Natural Tannins in Protecting Coconut Meal Protein Judging from the Protein Fermentability In Vitro. Animal Agriculture Journal. 1(1): 405416.

Zinn, R. and F. Owens. 1986. A Rapid Procedure for Purin Measurment and Its Use for Estimating Net Ruminal Protein Syinthesis. Canadian Journal of Animal Science. 66: 157-166. 